\title{
A Contractualist Reply
}

\section{Citation}

Scanlon, T. M. 2008. “A Contractualist Reply.” Theoria 66 (3) (June 28): 237-245. doi:10.1111/ j.1755-2567.2000.tb01166.x.

\section{Published Version}

doi:10.1111/j.1755-2567.2000.tb01166.x

\section{Permanent link}

http://nrs.harvard.edu/urn-3:HUL.InstRepos:26517529

\section{Terms of Use}

This article was downloaded from Harvard University's DASH repository, and is made available under the terms and conditions applicable to Open Access Policy Articles, as set forth at http:// nrs.harvard.edu/urn-3:HUL.InstRepos:dash.current.terms-of-use\#OAP

\section{Share Your Story}

The Harvard community has made this article openly available.

Please share how this access benefits you. Submit a story.

Accessibility 


\section{Reply to Pettit ${ }^{1}$}

\section{T. M. Scanlon}

I am of course pleased that Philip Pettit believes my view describes "a moral category that is intuitively of the first importance" even if he thinks it does not, as I had intended, capture the central idea of moral right and wrong. He refers to this moral category as "civility." This is not a name I would have chosen, since it may seem to suggest something that is merely a kind of politeness, but in what follows I will occasionally employ it as a convenient label. In responding to Pettit's thoughtful discussion, I will first consider some possible disagreements between us about the implications of my view for first-order moral questions and then turn to the deeper theoretical tension between my outlook and the consequentialist accommodation that he offers.

Although I agree that the class of actions that are right according to my view will not coincide with the class of optimific actions, the example he gives (of the rich person's duty to help the poor) does not seem to me to be an instance of this divergence. ${ }^{2}$ I do not see why he thinks that on my view the duty of a rich person to help someone in need cannot exceed the amount that he would be required to contribute if all equally rich people were to contribute the same amount. On the contrary, the reasonableness of rejecting a principle of mutual aid depends on the magnitude of the burden it would impose on a benefactor. Perhaps the most equitable principle would require these burdens to be shared in some way by all of those who are in a position to contribute. But even if

\footnotetext{
${ }^{1}$ I am grateful to Derek Parfit for helpful comments on a draft of this reply.
} 
this is so, it does not follow that a person who is in a position to alleviate someone's suffering is released from any obligation to do so if others refuse to share this burden. It might be reasonable to reject a principle requiring one to provide assistance when doing so would be a great burden, but this does not seem to be the case in Pettit's example. So I do not see why he thinks that contractualist morality would let his rich person off the hook.

Nor do I see why he thinks that according to morality as the contractualist understands it one never permitted to kill an innocent person, whatever the consequences of not doing so may be. He asks us to "imagine a situation where you can only save life on earth by killing an innocent person who is blocking the way to the all-important switch." (6) But, assuming that this person will perish along with the rest of us if the switch is not thrown in time, I do not see that it would be reasonable, from his point of view, to reject a principle permitting someone to kill him in order to get to the switch. What good would it do him? Moreover, even if his life were not threatened it is not clear that contractualist morality would forbid us to kill him in order, say, to save one hundred million others. I believe that when, as in this case, the harms to each person are the same, the rightness of an action can depend on the number of people affected. I argue this for the case of saving the greater number, ${ }^{3}$ and I believe that that argument can be extended to some cases of killing as well. This extension is necessary not only to handle cases involving the potential death of millions, but also to deal with more modest cases, such as

\footnotetext{
2 "Contractualism and Consequentialism: An Exchange," p. 2. Subsequent page references in the text will be to this article.

${ }^{3}$ In What We Owe to Each Other (Cambridge, Mass.: Harvard University Press, 1998) pp. 229-241.
} 
the famous trolley problem, in which it is permissible to switch the trolley, thus killing one instead of letting five die.

A morality that permits killing in such cases is not necessarily a form of consequentialism. It would remain non-consequentialist if, for example, it permitted switching the trolley in order to save the greater number but did allow killing in other situations with the same structure of consequences, such as cases in which five could be saved by killing one and distributing his organs. I myself believe that the possibility of saving others in this way not only does not justify killing, but also does not justify declining to save a potential provider of organs when one could easily do so. It is notoriously difficult to give a satisfactory account of all of these cases, but this is a problem for the consequentialist as well as the non-consequentialist, at least if it is agreed that the trolley and transplant examples require different answers. The problem for a nonconsequentialist is to explain the permissibility of switching the trolley. The consequentialist has the opposite problem of explaining why it should not also be permissible to kill (or fail to save) in the transplant case.

I have so far been arguing that where extreme actions of the kind Pettit mentions are, intuitively, justifiable, they can be shown to be permitted by the morality of right and wrong that contractualism describes ("civility" as Pettit calls it.) If this argument succeeds, then it is not necessary to consider these as cases in which actions that civility forbids may be justified by considerations external to it. I do not exclude the possibility of cases of the latter sort. It makes sense to ask whether, despite the fact that an action would be wrong, it may nonetheless be what one has most reason to do. But one need not see the situations Pettit cites as raising this question. 
Let me turn now to the more theoretical question of how a non-consequentialist moral view of the kind I have described might be reconciled with, or accommodated within, a consequentialist perspective. It will be helpful at the outset to distinguish two ways in which one view might be reconciled with another.

Let $\mathrm{R}$ and $\mathrm{S}$ be two normative doctrines: two views about what we have reason to do. Call the considerations that $\mathrm{R}$ tells us to take as reasons $\mathrm{R}$-reasons, and the actions that $\mathrm{R}$ tells us we have compelling reason to perform R-actions, and similarly for Sreasons and S-actions. The project of reconciling $\mathrm{R}$ and $\mathrm{S}$ could be understood in at least two ways. On the first, weaker interpretation, all that is involved is showing that the two views do not conflict: that being guided by the considerations that $\mathrm{R}$ identifies as reasons will not lead us to act in ways that are contrary to the requirements of S. This might be done in several different ways. It might be shown that $\mathrm{R}$ and $\mathrm{S}$ deal with entirely separate classes of actions, and hence cannot conflict. Or it might be that while they do overlap, R-actions turn out (as a matter of contingent fact) to also be S-actions, because (as a matter of contingent fact) whenever R-reasons count decisively in favor of a certain action S-reasons do so as well.

A second, stronger project of reconciliation would undertake to show that Rreasons are in fact also S-reasons, and thus that $\mathrm{R}$ is not merely consistent with $\mathrm{S}$ but in fact endorsed by it. Establishing this stronger claim would of course establish the weaker one as well, and it might be that, for some R and S, carrying out the stronger project of reconciliation is the only way to carry out the weaker one. But the two projects may nonetheless reflect different attitudes toward R. Someone who regards the weaker project as sufficient may think that the claims of $\mathrm{R}$ do not stand in need of justification but that 
they do need to be defended against the objection that they conflict with the reasons endorsed by S. By contrast, if one thinks that this weaker kind of reconciliation is insufficient, this seems to reflect the view that the claims of $\mathrm{R}$ need to be justified in terms of $\mathrm{S}$.

An example will illustrate the difference. In Chapter 4 of my book, I undertake to show how friendship (the class of reasons that one takes oneself to have if one is a friend) can be reconciled in the first, weaker sense with the morality of right and wrong as my contractualism describes it (what Pettit calls "civility.") ${ }^{4}$ That is, I try to show that full acceptance of morality is not incompatible with friendship, but I make no attempt to show that the reasons involved in friendship follow from morality so understood. To hold that the latter is necessary would be to claim that friendship is not adequately conceived as an autonomous value; that in order to be accepted and taken seriously it needs to be shown to be a special case of moral requirements, and I do not believe that this is the case. I go on suggest that morality as I describe it can be reconciled in this weaker sense with a wide range of other "autonomous" values.

I thus have no objection to the project of showing that the morality of right and wrong as contractualism describes it can be reconciled in this weaker sense with consequentialism (the thesis that what we have reason to do is to act so as to maximize expected neutral value), although I do not think this project is likely to succeed. Like most defenders of non-consequentialist moral views, however, I would resist the idea that non-consequentialist morality needs to be reconciled with consequentialism in the second, stronger sense.

\footnotetext{
${ }^{4}$ What We Owe to Each Other, pp. 160-166.
} 
Much, then, depends on the kind of reconciliation that is being offered and the reasons for offering it. Pettit sometimes seems to be proposing only a reconciliation of the first, weaker kind. This is suggested, for example, when he says,

The idea is not that the practice-related reasons and motives become instrumental in character, under a consequentialist endorsement: it is not that they become subsumed in reasons and motives derived from the project of doing the most overall good. The idea, rather is that those autonomously sourced reasons and motives come to be reconciled with—get to be seen as consistent with—that project. (8)

Similarly, speaking of people who act out of friendship while accepting a consequentialist reconciliation, he says, Their recognition that behaving like a friend is for the best will explain, not their acting out of friendship, but rather their not seeking to eliminate or restrain their friendship-related inclinations. They act out of friendship with a clear, consequentialist conscience. But while that conscience monitors their behaviour, it does not motor it. (5)

These passages, particularly the phrase "autonomously sourced" and the contrast between "monitoring" and "motoring" reassuringly suggest that the reasons that "civility" involves are merely to be freed from the possible objection that they are incompatible with consequentialism rather than shown to be justified by it. But elsewhere Pettit contrasts what he calls my "canonisation or sacralisation of the practice [of civility]" with his account, which, he says, allows us to acknowledge the importance of distributive justifiability "without abandoning an essentially consequentialist perspective on what it is 
that ultimately makes a choice right or wrong." (6-7) This contrast suggests that the reasons that civility involves stand in need of justification, which a consequentialist accommodation can provide. The phrase "canonization or sacralisation" in particular is reminiscent of the familiar utilitarian charge of "rule worship," and seems at least at first glance to be in conflict with the idea that reasons of civility are to be seen as "autonomously sourced."

In order to sort out this apparent conflict, we need to move beyond the framework I have so far employed and consider in more detail how a consequentialist accommodation of the kind Pettit proposes would proceed. As Pettit makes clear, what he is proposing is not a reconciliation of friendship, or civility, with a form of consequentialism that holds that we should choose, in each situation, an action which has greatest expected neutral value. The consequentialism he has in mind recognizes that it is sometimes best to "forsake case-by-case calculation about consequences." (8) And he suggests that this is true in the cases of friendship and civility: best consequences are promoted by adopting the reasons and motives that characterize a friend (or a deontological moralist) while "monitoring" these dispositions by being alert for situations in which there are good consequentialist reasons to abandon them.

Taking this into account, it might be said that Pettit's form of consequentialist accommodation does not fit either of the models I have described. On the one hand, the reasons and motives of friendship and civility are not merely shown to be consistent with consequentialism but also to be justified in consequentialist terms by the fact that they constitute "highly beneficial practices." (5) But what is justified is the practice of taking

\footnotetext{
${ }^{5}$ But I will consider below another way of understanding this remark.
} 
these reasons and motives at face value as not merely instrumentally useful but as “autonomously sourced.” (8)

As Pettit says, this consequentialist strategy is well-known. Equally well-known is the fact that non-consequentialists have not found it entirely convincing. ${ }^{6}$ The problem concerns the role that consequentialist justification is supposed to play in the thinking of the person who has adopted friendship or civility "with a clear, consequentialist conscience." (5) If the beneficial consequences of these practices play no positive justificatory role in such a person's thinking, and his or her consequentialist thoughts are only of a "monitoring" variety (that is, consist only in checking for considerations that could call for setting the normal requirements of civility or friendship aside) then we are on uncontroversial ground since, as I have argued above, a non-consequentialist can agree that exceptions to these normal requirements are sometimes justified. But on this construal the consequentialist character of the accommodation seems to have evaporated. If, on the other hand, a person's acceptance of the reasons and motives typical of friendship or "civility" is to depend on his or her awareness of the beneficial results of these attitudes, then the recommended outlook remains consequentialist but the charge of instrumentalism has at least prima facie force.

The amount of force that it in fact has depends crucially on what the "beneficial consequences" are taken to be. The charge has greatest force when these consequences are identified with such things as the benefits one gains from the help and support of friends and from the entertainment that their company provides. An outlook which took the reasons one has to be loyal to one's friends to depend on benefits of this kind would be implausibly instrumentalist, and I believe that an analogous point could be made about 
an outlook which took the reasons one has to behave morally towards others to consist entirely in the benefits of their reciprocal restraint.

But this is clearly not the kind of justification that Pettit has in mind. When he speaks of civility as "a palpably desirable form of community" (5) it seems fair to assume that he has in mind not only the benefits that individuals derive from general restraint from violence, willingness to cooperate, and so on but also the intrinsic value of living with others in a way that expresses mutual concern and respect. Similarly, we may suppose that the beneficial consequences of friendship include the intrinsic value of such relationships.

When these intrinsic values are taken into account, the difference between consequentialist and non-consequentialist positions becomes more subtle but does not, I think, entirely disappear. A non-consequentialist who understands the value of friendship will not only see reasons to be loyal to his or her friends but will also see friendship as good - as something one has good reason to want to have in one's life. Similarly, someone who understands the morality of right and wrong in the way contractualism describes it will not only see reason to do what it requires but also think that it is good to live in this way - that one has reason to be the kind of person who does this. So a nonconsequentialist and a consequentialist of the kind Pettit describes can both recognize two classes of reasons where friendship and civility are concerned: reasons to do what the practice in question involves and reasons to want to have the kind of life that involves being moved by these reasons. What they disagree about is how these two classes of reasons are related.

\footnotetext{
${ }^{6}$ See, for example, Bernard Williams's discussion in Utilitarianism: For and Against.
} 
These classes contain reasons of two different kinds: the first class, reasons for acting in certain ways (for example, reasons to keep one's promises or be loyal to one's friends), the second, reasons to want certain things to be the case, namely that one is the kind of person who acts on reasons of the kinds just mentioned or that one lives the kind of life in which one does this. This difference may seem rather slight, particularly when we bear in mind that the reasons of the latter sort that are in question reflect the intrinsic value of a certain kind of person or a certain kind of life. Both kinds of reasons are in a broad sense moral reasons. But they are nonetheless distinct: a reason not to break a promise is not identical with a reason to bring it about that one is the kind of person who keeps promises or that one lives a life of fidelity, much less (since Pettit's consequentialism is concerned with expected neutral value) with a reason to promote the valuable kind of community in which, among other things, people see reason to keep their promises. Pettit's consequentialist accommodation does not identify these two kinds of reasons, but it does involve the claim that reasons of the latter sort are the fundamental reasons on which reasons of the former sort depend. It is because there is reason to want people or communities of a certain kind to exist that we have reason to think and act in the way that is required in order for this to be the case. We are justified in thinking and acting in the ways that civility requires because in so doing we will "give rise to a palpably desirable form of community.” (5) This strikes me as implausible.

I do not want to sound ungrateful or "unaccommodating" by harping on the ways in which Pettit's friendly explanation of how my view could be acceptable to a consequentialist is not entirely acceptable to $m e$, as a non-consequentialist. (After all, as a non-consequentialist, I am not part of the audience to which that explanation is 
addressed.) My aim, however, is to make as clear as possible the way in which these two outlooks diverge. As I have said, consequentialists and non-consequentialists can agree that we have reason to think and act in the ways that contractualist morality ("civility") requires and that it is a good thing that there should be communities of people who think and act this way. The disagreement comes when the 'and' in this sentence is replaced by a 'because.' I reject this replacement because it seems to me to get the relation between these two classes of reasons wrong. This is the reaction one would expect from someone who sees the reasons of civility as "autonomously sourced." But why not simply accept this view of things? Why prefer the consequentialist account?

I can think of two rationales for doing so. The first is the very general idea that all reasons must ultimately be grounded in the values of states of affairs, and that reasons for or against acting in certain ways that are not, on their face, concerned with the consequences of so acting, must be shown to be so grounded. The idea is that this is so even when, as in the present case, the reasons in question concern intrinsic moral properties: there can be, it is maintained, intrinsic moral reasons to bring about certain states of affairs, but not intrinsic moral reasons for or against certain kinds of action. I have argued against this general view elsewhere, ${ }^{7}$ and will not repeat those arguments here.

The second rationale is more substantive. It is based in the conviction that circumstances can arise in which the requirements of friendship or of civility must be breached for the sake of the greater good and on the idea that this cannot be explained in a plausible way if these requirements are taken to have a non-consequentialist basis. If the ultimate moral basis of these requirements is a consequentialist one, we can explain, 
in a way that is plausible and not ad hoc, how and when they can justifiably be set aside. But there is no way of doing this if their foundation is not ultimately consequentialist. (This suggests a second reading of what Pettit means when he speaks of "canonization" and "sacralisation"- namely that a non-consequentialist account civility rules out exceptions to its requirements.)

I have responded to this argument above, by explaining how a nonconsequentialist view can account for cases of the kind Pettit cites in which it is permissible to do things which moral requirements normally forbid. Here I would add only the observation that the positive consequential values that Pettit's consequentialist accommodation of friendship and civility depend on do not seem to play a role in deciding what one should do in these extreme cases. In deciding whether it is permissible to betray a friend, break a promise, or kill an innocent person in order to prevent something horrible from happening, what we must weigh against the importance of preventing this horrible event are the claims of the friend, promisee, or victim, not the fact that a friendship will be lost, or a palpably desirable form of community will be damaged. Even if we were deciding, not whether an act is permitted by the morality of right and wrong that comprises "civility" but whether one has sufficient reason to do it despite the fact that it is not permitted, what would be set against the reason we have to prevent the threatened disaster would be the reason we have to treat others only in ways that are "distributively justifiable," not the degree to which the neutral value of the resulting state of affairs will be decreased if we fail to act in this way.

\footnotetext{
${ }^{7}$ In What We Owe to Each Other, pp. 50-55, 84.
} 